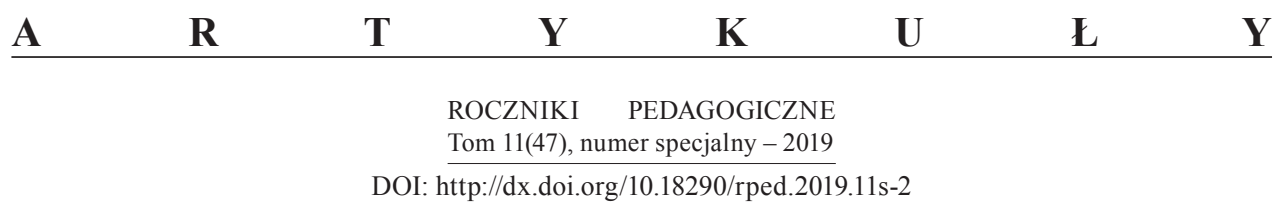

KS. MARIAN NOWAK

\title{
AKSJOLOGIA \\ WSPÓŁCZESNEJ PEDAGOGIKI RESOCJALIZACYJNEJ JAKO PODSTAWA JEJ SUKCESU
}

Według Gino Corallo nie ma historii czy też jakiejkolwiek epoki, w której nie byłoby wartości, ale też nie ma wartości bez wolności, która sprawia, że możemy mówić dalej o sumieniu, odpowiedzialności, zobowiązaniach i zadaniach moralnych (Corallo, 2010).

Ten właśnie ostatni wymóg - wolności, jaki występuje w odniesieniu do wartości, sprawia, że gdy mówimy o resocjalizacji czy osobach uwięzionych, znajdujemy pewien wewnętrzny opór, aby w takie konteksty, jak resocjalizacja i także pedagogika resocjalizacyjna wprowadzać problematykę aksjologiczną.

Problematyka ta jednakże wynika nie tylko z odpowiedzi na aktualne problemy, lecz także wiąże się z doświadczaniem wartości, również przez pokolenia poprzedzające nas, które rozwiązując swoje aktualne problemy, nakreśliły pewien styl życia i określone kryteria oraz priorytety, którymi kierowali się oni sami i które uznali za istotne dla nadchodzących pokoleń.

Główny problem, na który chce odpowiedzieć niniejszy artykuł, brzmi: Jaka jest rola wartości w sukcesie oddziaływań resocjalizacyjnych?

Odpowiadając na ten problem, najpierw wychodzimy od ogólnego określenia roli wartości w wychowaniu, następnie wskażemy na specyfikę procesu resocjalizacji, aby na koniec podjąć zagadnienie roli wartości w procesie skutecznej resocjalizacji.

Ks. prof. zw. dr hab. MARIAn NowaK - kierownik Katedry Pedagogiki Ogólnej, Instytut Pedagogiki, Katolicki Uniwersytet Lubelski Jana Pawła II, Al. Racławickie 14, 20-950 Lublin; e-mail: marian.nowak@kul.pl; ORCID: 0000-0001-6957-9979 


\section{WARTOŚCI I AKSJOLOGIA W WYCHOWANIU I W PEDAGOGICE}

Wychowanie jest wprowadzaniem i swoistym „osadzaniem człowieka”, jako uczestnika i aktora zachodzących zdarzeń i dziejącej się historii, w konkretnym jej miejscu i w konkretnych jej uwarunkowaniach. Jeśli zgadzamy się z tym stwierdzeniem, jako oczywistym stanem rzeczy, to łatwo zauważamy, że wychowanie nie może się dać zredukować do jednego z biegunów, które raz po raz dają o sobie znać w postaci: albo indywidualność - albo życie zbiorowe, lecz konieczne są oba. Podobnie człowiek nie może pozostawać zamknięty w samym sobie, ale jest on, jako jednostka, zarazem ustawicznie otwarty na obiektywny świat wartości, który powinien najpierw poznawać, następnie uznać jako ważny dla siebie i go sobie przyswajać, w otwartości na innych, na społeczny wymiar jego egzystencji.

Szczególna rola przypada w tym dziele wychowawcy, który - zwłaszcza jeśli ma chociaż odrobinę talentu pedagogicznego - powinien umieć pokazać te wartości wychowankowi tak, aby one zaczęły go zachwycać. Poza talentem pedagogicznym w ukazywaniu określonych wartości i powodowaniu fascynacji wychowanka nimi, oczywiście istotnym wsparciem oddziaływań wychowawcy staje się także jego świadectwo życia tymi wartościami.

Pytania podstawowe związane ze skutecznym przekazywaniem wartości są zatem następujące: Jak wychowawca realizuje wartości w swoim życiu? Jakimi kryteriami i priorytetami się kieruje? oraz: Jak nauczane wartości wyraża w praktyce swojego życia na co dzień? Jak czyni wrażliwym na nie wychowanka i jak do nich wychowuje?

Katarzyna Olbrycht mówi o możliwościach edukacji aksjologicznej, której celem jest zwiększanie kompetencji związanej ze znajomością problematyki wartości i wartościowania oraz podejmowania świadomych, samodzielnych aksjologicznych decyzji (Olbrycht, 2000).

Tę problematykę w pedagogice współczesnej uprawia i ujmuje aksjologia pedagogiczna czy aksjologia wychowania. Aksjologia (jako nauka o wartościach) stanowi dział filozofii ukierunkowany na wartości. Z kolei aksjologia wychowania jest rozumiana jako dział w pedagogice zajmujący się analizą źródeł wartości w wychowaniu, ustalaniem ich hierarchii i ich analizą treściową oraz ich uzasadnianiem. Czasami aksjologię ujmuje się jako wręcz subdyscyplinę pedagogiczną. Niezależnie od tego, jak traktowana jest aksjologia i aksjologia wychowania w wielorakich podejściach współczesnej myśli pedagogicznej, od przełomu XIX/XX wieku jest ona istotnym działem pedagogiki i jej subdyscyplin, w tym także pedagogiki resocjalizacyjnej.

Najczęściej problematyka wartości występuje w związku z celami wychowania. Mówiąc o celach wychowania, mamy zwykle na myśli określone stany 
rzeczy, których osiągnięcie uważamy za pożądane. Formułowanie celów wychowania wymaga przezwyciężenia dwóch bardzo niebezpiecznych tendencji: 1) ustalania celów utopijnych oraz 2) w ich ustalaniu popadania w skłonność do zbyt wąskiego pragmatyzmu.

Wychowanie człowieka nie może być pojmowane jako proces związany tylko z genetyką i wrodzonymi cechami - najwyżej wspieranymi przez wychowawcę - ani też postrzegane jako efekt oddziaływań zewnętrznego środowiska i swoistego urabiania wychowanka. Rozwojowy charakter całej egzystencji człowieka jest teleologiczny i w konsekwencji otwarty na cały otaczający świat, dokonując się oczywiście w sposób ukierunkowany. Oznacza to potrzebę ciągłej aktywności w działaniu i stały wysiłek człowieka zmierzającego ku czemuś - oznacza zatem aktywność rozpostartą między sobą aktualnym a sobą możliwym. Człowiek jest efektem wpływu swojego otoczenia społecznego, także wpływu kultury, a nie tylko tego, co przynosi ze sobą w momencie urodzin. Wychowanie zatem jest procesem ustawicznego stawania się człowieka i przez to transcenduje wymiar naturalnego wzrostu czy rozwoju, stając się procesem nade wszystko duchowym (Fullat, Genis, 1999, s. 202).

W oddziaływaniach wychowawczych i wzajemnych relacjach wychowawca-wychowanek należy zatem zatroszczyć się świadomie, celowo i w pełni o aksjologicznie uzasadniony dobór wartości, które chcemy, by stały się udziałem wychowanka. Jeśli wychowawca nie stawiałby sobie żadnego celu, to wówczas nie byłby też potrzebny, aby zajmować się wychowankiem. Wychowanie i nauczanie są nie do pomyślenia bez postawienia problemu celu wychowania, a więc nie istnieją one bez wartościowania i bez wartości. To właśnie dlatego aspekty aksjologiczne nie mogą zniknąć z pola widzenia pedagogiki i szkolnej praktyki edukacyjnej, a zwłaszcza ze wzajemnych osobowych relacji nauczyciel-uczeń, wychowawca-wychowanek.

Specyfika sytuacji człowieka (jej antropologiczne i aksjologiczne oraz ontologiczne podstawy) wyraźnie wyodrębnia egzystencję ludzką od tej innych istot żywych. Człowiek nie potrafi przeżyć (czyli zachować życie), jak to jest możliwe na przykład w przypadku zwierząt, działając tylko w ramach odpowiadania na potrzeby chwili i w kontakcie z bezpośrednią rzeczywistością, lecz w swojej aktualnej teraźniejszości potrzebuje on innej jeszcze perspektywy własnej egzystencji - tej biegnącej ku przyszłości i tej zachowującej pamięć przeszłości. Nade wszystko potrzebuje on projektowania swoich celów, które osiąga lub będzie mógł osiągać w dłuższym lub krótszym czasie (Kamiński, 1986).

Wskazuje się często też na odkrywaną w biografiach ludzkich prawidłowość, że im bardziej rozbudzony jest umysł człowieka, im większa jest jego wiedza, 
tym dalszy jest zakres jego planowania. Ma to swoje przełożenie także na społeczne konteksty życia, a mianowicie podkreśla się, że im wyższe i bardziej złożone jest życie danych społeczności, tym bardziej wymagają one szerszego i bardziej złożonego ujęcia zakresu ich aktywności, jak również pewniejszego i poszerzonego zakresu wzajemnych zobowiązań i paktów. Domagają się też one większych i pewniejszych zabezpieczeń dla umów i paktów zawieranych między osobami i grupami porozumień (Heschel, 2014).

Zarówno w wymiarze jednostkowym, jak i społecznym swojej egzystencji człowiek potrzebuje jednak nie tylko tego rodzaju uregulowań prawnych czy formalnych, lecz także oparcia się na pewnej stałości i wzniosłości natury duchowej, czyli również na pewnych wartościach.

Tak otwiera się cała grupa problemów związanych z obecnością wartości $\mathrm{i}$ aksjologią w pedagogice, które wyrażamy w formie pytania: Czy wychowanie bez celu? A skoro mowa o celu, to konieczne staje się odniesienie się do wartości. Czym jednak są wartości? Jak one istnieją? Skąd pochodzą?

W odpowiedzi na te pytania możemy przywołać trzy stanowiska związane już od starożytności z zastanawianiem się, skąd ludzie wiedzą o dobru. Pierwsze stanowisko wiązane było z odpowiedzią starożytnych, że to bogowie Olimpu powiedzieli nam o dobru; drugie stanowisko wiązano ze wskazaniem na ludzkie doświadczenie wartości, a zatem sami ludzie doświadczali dobra i do niego dążyli?

Chrześcijaństwo reprezentuje w tej dyskusji trzecie, pośrednie stanowisko, zauważając i akcentując z jednej strony Prawo Boże (Przykazania) dane nam ,z góry”, ale z drugiej strony dostrzegamy też odwoływanie się do ludzkiego doświadczenia. Przykład takiego podejścia daje sam Jezus Chrystus. Między innymi w Przypowieści o miłosiernym Samarytaninie (Łk 10, 30-37) możemy zauważyć, jak z jednej strony odwołuje się do przykazań i wskazuje na potrzebę ich zachowywania, a zwłaszcza odnosi się do przykazania miłości Boga i bliźniego, z drugiej strony Jezus odwołuje się do doświadczenia ludzi, przytaczając dla wyobraźni swoich słuchaczy historię miłosiernego Samarytanina i człowieka pobitego przez zbójców.

Na pytanie uczonego w Piśmie, „Kto jest moim bliźnim?”, Jezus odpowiada obrazowo, zarysowując $\mathrm{w}$ formie przypowieści doświadczenie możliwego postępowania ludzi wobec tego, który wpadł w ręce zbójców i w kondycji człowieka „na wpół żywego” został pozostawiony przez nich przy drodze (Nowak, 2012).

W jaki sposób natomiast można obdarzać wartościami i jak do nich wychowywać?

Odpowiedź na to pytanie możemy zacząć od stwierdzenia ogólnie uznawanego, że nie ma ludzi niekierujących się wartościami. W istocie cały problem 
i nieporozumienia tkwią nie tyle w tym, że ktoś chce coś osiągnąć, że dochodzi swoich praw i chce poprawić swoją sytuację, ktoś chce lepiej wiedzieć, więc się uczy, czy też chce więcej zarobić, lepiej prosperować itd.

Istota problemu tkwi natomiast w tym, co dany człowiek widzi jako największą własną wartość. Nie tyle zatem ważne jest stwierdzanie o fakcie, że ktoś zabiega o jakieś wartości, lecz o jakie wartości i w czym on te wartości dostrzega? Nie tyle jest ważne, że ktoś opowiada się za życiem, za pomyślnością czy nawet za modną dzisiaj - wellness, ile to, czy kształt tego życia, za jakim się opowiada, jest jeszcze ludzki?

Już wyżej przywołane stanowiska potwierdzają fakt, że cele są konieczne w ogóle dla człowieka, a w związku z tym są tym bardziej konieczne dla jego wychowania, jak również dla resocjalizacji. Wielokrotnie powtarzane stwierdzenie, że nie ma wychowania ani nauczania bez wartości i bez celów, ma pełne swoje uzasadnienie w praktyce życia. Jeśli kogoś wychowuję lub chcę czegoś nauczyć, to stawiam cele i wartościuję - wcześniejszy stan uznając za gorszy od tego, jaki proponuję jako pewne dobro. Na ten temat zabierają głos także teoretycy i badacze natury ludzkiej już od starożytności, do których przykładowo możemy się odwołać:

- Platon (ok. 427-347 przed Chr.) podkreślał, że każdy, kto chce prowadzić ludzi, a zwłaszcza pedagog czy człowiek polityki, powinien wiedzieć, kogo on i dokąd ma prowadzić;

- nie brakuje wśród współczesnego spectrum teorii i koncepcji antropologicznych takich, które analizując na przykład psychiczną kondycję człowieka i w ogóle dotykając podstawowych prawidłowości jego życia, wskazują na charakteryzującą naturę ludzką celowość. Mówi o tym między innymi teoria psychologii indywidualnej Alfreda Adlera (1870-1937). Według tej teorii człowiek jest istotą ukierunkowaną na cel. Celowość wyznacza jednostkowy styl życia, spójność działania osoby oraz motywy ludzkiego funkcjonowania i działania (Nowak, 2012).

Zdaniem Grażyny Klimowicz odmienność norm obowiązujących w różnych grupach społecznych, do których młody człowiek przynależy, niejasność bądź rozbieżność obowiązującego systemu wartości utrudniają określenie siebie, własnego spójnego systemu wartości i oczekiwań wobec otoczenia. Oznacza to, iż w relacjach nauczyciel-uczeń należy pomóc uczniom w rozwijaniu umiejętności odpowiedzialnego wyboru i kierowania sobą (Rylke, Klimowicz, 1992).

Zaangażowanie uczestników (nauczycieli i uczniów) w sytuacji edukacyjnej o dialogicznym charakterze relacji interpersonalnych jest optymalnym czynnikiem rozwoju osobowego podmiotów tego procesu. Edukacja w swej istocie jest sztuką okazywania zainteresowania drugim człowiekiem, możliwościami jego 
ciągłego rozwoju i sztuką refleksji, zadumy nad własnymi postawami i czynami w optyce słusznej etyki i określonej aksjologii, które to procesy i wzajemne relacje dumnie nazywamy „nauczaniem” i „wychowaniem” (Kunowski, 2003).

Relacje między nauczycielem i uczniem w procesach edukacyjnych powinny opierać się na bezwarunkowej akceptacji ucznia przez nauczyciela. Należy okazywać szacunek dla godności wychowanka. Wyraża go m.in. optymistyczna postawa wychowawcy wobec uczniów, wiara w to, że każdy uczeń jest w stanie rozwinąć się i wznieść na choćby minimalnie wyższy poziom. Chodzi tu nie tylko o rzeczywisty wzrost wiedzy i faktyczny rozwój funkcji psychicznych, lecz także o świadomość i ich poczucie u uczniów. A to może dokonać się tylko w odniesieniu do najbliższego otoczenia w relacji do drugiej osoby. Istotnym komponentem prawdziwego procesu wychowawczego jest immanentnie tkwiąca w nim relacja „człowieka do człowieka”. Wychowanie zaś jest „całokształtem sposobów i procesów pomagających istocie ludzkiej, zwłaszcza przez interakcję, urzeczywistniać i rozwijać swoje człowieczeństwo" (Tarnowski, 1990, s. 66).

\section{PROCES RESOCJALIZACJI A PROCES WYCHOWANIA}

Tak jak wyżej wskazywano, że nie ma wychowania bez wartości i celów, tak możemy też stwierdzić, że nie może być resocjalizacji bez wartości i bez celów. Również proces resocjalizacji, jak każda działalność ludzka, jest ukierunkowany na cele i wartości.

W resocjalizacji możemy mówić najpierw o celach podobnych jak wszystkie inne cele związane zwłaszcza z rozwojem, z socjalizacją i inkulturacją: utrwalanie relacji do wszystkiego, co dobre, prawdziwe i piękne w kulturze, postawa opieki, akceptowania i respektowania oraz chronienia innych osób, relacji międzyosobowych, funkcji poznawczych i emocjonalnych, takich wartości, jak dojrzałość i osiągnięcia społeczne, wywiązywanie się z ról społecznych, integracja psychiczna, stymulacja twórcza, usprawnienia duchowe, nawyki fizyczne itp. Wszystkie te cele wynikają zwłaszcza z antropologicznych podstaw wychowania wyznaczanych przez antropologię filozoficzną, która do osiągnięcia celów wskazuje na: naturę ludzką; kształtowanie intelektu, woli, emocji oraz mechanizmów kontroli wewnętrznej; utrwalenie postaw chroniących osoby i relacje osobowe oraz tego, co jest cenne dla człowieka, czyli wartości; wyćwiczenie możliwości fizycznych i duchowych człowieka (Sobczak, 2008).

W tym ujęciu proces resocjalizacji prowadzi do integralnego rozwoju sfery fizycznej - zdrowia i sprawności fizycznej, sfery emocjonalnej i psychicznej, 
sfery poznawczej i postaw prospołecznych, także sfery duchowej i wsparcia w kształtowaniu własnej sfery światopoglądowej.

Bliższa analiza problematyki aksjologiczno-wychowawczej pozwala zauważyć, iż człowiek, jako podmiot wychowania, ma swoistą charakterystykę aksjologiczną. Wszelki ideał czy model wychowawczy musi wyrastać ze zrozumienia aksjologicznej specyfiki osobowości człowieka, wiedza zaś o wychowaniu musi opierać się na wiedzy o wartościach i o naturze człowieka (Cichoń, 1980).

W tym miejscu należy zająć się już samym fenomenem i problemem wartości. Po pierwsze, konkurują obecnie dwa pojęcia: „dobro” i „wartości”. „Dobro” pochodzi z klasycznej filozofii bytu, „wartości” z nowożytnej filozofii świadomości. Można dla uproszczenia potraktować pojęcia te jako tożsame i pominąć referowanie sporów filozoficznych wokół nich, a zająć się wyjaśnianiem istoty zagadnień aksjologicznych. Wyróżniamy dwa rodzaje wartości o szczególnie ważnym znaczeniu. Jedne z nich istnieją na zewnątrz człowieka, w świecie, w materii zewnętrznej, w postaci gotowej lub z niej wytwarzane (wartości odżywcze, społeczne, cywilizacyjne, kulturowe itp.). Można je nazwać wartościami pozaosobowymi (transcendentnymi). Te drugie można nazwać wartościami osobowymi, gdyż wyrażają one pewien sposób istnienia osoby ludzkiej (wartości duchowe, immanentne). I tak jak człowiek przewyższa sobą cały świat przyrody, tak też wartości osobowe przewyższają wartości przyrodnicze, cywilizacyjne, kulturowe, społeczne (Gałkowski, 1996).

Jeśli człowiek zna prawdę o człowieku i widzi jego godność, podejmując zobowiązania wynikające $z$ tej prawdy, odkrywa normę moralną i działa ze względu na ową normę, to działanie to dopiero wówczas jest realizowane na płaszczyźnie moralnej. „Wartości moralne - jak twierdzi Dietrich von Hildebrand - są węzłowym problemem świata; brak moralnych wartości jest największym złem, gorszym niż cierpienie, choroba, śmierć, gorszym niż upadek kwitnących kultur [...], lepiej krzywdy doznać, niż ją wyrządzić" (Hildebrand, 1982, s. 10).

\section{SKUTECZNA RESOCJALIZACJA I JEJ WARTOŚCI}

Znane są różne rodzaje i formy resocjalizacji, których bliżej nie ma potrzeby analizować obecnie, lecz skoncentruję się na resocjalizacji, którą Henryk Machel określa jako „penitencjarną” i rozumie ją jako oddziaływania psychokorekcyjne stosowane wobec skazanych na karę pozbawienia wolności (Machel, 2003).

Tego rodzaju resocjalizacja realizuje dwa rodzaje celów, które możemy określić jako: 1) cel minimum oraz 2) cel maksimum. Bliżej charakteryzując te rodzaje celów możemy stwierdzić: 
Ad 1) Cel minimum określa taki stan osobowości więźnia, który umożliwi mu funkcjonowanie w społeczeństwie po opuszczeniu więzienia bez naruszania norm prawnych. Osiągnięcie tego rodzaju celu zabezpiecza byłego przestępcę przed recydywą. Jest to w sumie jedynie proces jakiejś readaptacji podstawowej do wymagań życia społecznego.

Ad 2) Cel maksimum można określić jako taki stan osobowości więźnia, który umożliwi mu funkcjonowanie w społeczeństwie nie tylko w taki sposób, aby nie naruszać norm prawnych, lecz także jako osoba respektująca istotne i ważne w życiu społecznym normy moralne.

W tym ostatnim przypadku były przestępca i więzień po opuszczeniu więzienia jest chroniony zarówno przed konfliktem z prawem, jak i przed konfliktem z ogólnie obowiązującymi normami prawnymi. Więzień, który odbył karę pozbawienia wolności (w części lub w całości), może podjąć trud układania sobie życia w zgodzie z podstawowymi standardami społecznymi.

Podczas gdy pierwszy cel (cel minimum) oznacza zatem osiągnięcie powstrzymywania się od naruszania norm prawnych, to cel drugi (maksimum) jest zorientowany zarówno na reintegrację i readaptację społeczną więźniów, jak i na zminimalizowanie nieprzystosowania społecznego aż do całkowitej jego likwidacji oraz uczynienie byłego więźnia także twórczym (Machel, 2001).

Byłoby tutaj miejsce do wprowadzania zwłaszcza wartości odpowiedzialności. Właśnie kategoria „odpowiedzialności” w szczególny sposób domaga się w każdej sytuacji, gdy jest używana, wyraźnej deklaracji co do sposobu traktowania wartości. Za Romanem Ingardenem możemy stwierdzić, że nie wydaje się możliwe mówienie o odpowiedzialności poza dobrem i złem:

Gdyby nie istniały żadne wartości pozytywne i negatywne oraz zachodzące między nimi związki bytowe, wtedy w ogóle nie mogłaby istnieć żadna prawdziwa odpowiedzialność, a także żadne spełnienie postawionych przez nią wymagań. [...] Także odpowiedzialne działanie byłoby bezsensowne i bezcelowe, gdyby się w nim nie liczyć z wartościami, nie uwzględniać ich istnienia czy możliwego unicestwienia (Ingarden, 1975, s. 107).

Do tych wartości możemy zaliczyć wartości poznawcze, takie jak odkrywczość, twórczość, prawdziwość. U ich podłoża znajduje się prawda, która stanowi cel i istotę poznania.

Klasyczna pedagogika właśnie prawdzie przyznała prymat w strukturze wartości. Współcześnie wskazuje się na odczytywanie i poszukiwanie wartości uniwersalnych, silnie zakorzenionych w tradycji humanistycznej i w doświadczeniu ludzkim. Charakteryzują się one powszechnością i trwałością. Należą 
do nich: prawo do życia i wolności, swobody obywatelskie, podmiotowość i tożsamość człowieka, pokój i demokracja, zdrowie i jego ochrona, praca i godziwy poziom życia, prawo do samorealizacji, założenia rodziny i życia w rodzinie lub w stanie wolnym.

Chociaż systemy wartości wydają się współcześnie dalece zróżnicowane, są one na ogół powszechnie akceptowane i na tyle powszechne, że można je uznać za ogólnoludzkie. Takimi są zwłaszcza wartości wskazujące na człowieka i jego egzystencję czy też na ludzką naturę i dążenie do dobra (Czerny, 1998).

Szczególną rolę w wyznaczaniu wartości dla procesu resocjalizacji, zdaniem Sławomira Sobczaka, może pełnić teleologia resocjalizacji, której podstawami są: aksjologia i realistyczna antropologia (Sobczak, 2008). W tym ujęciu to właśnie człowiek jest przyczyną i punktem wyjścia przy rozpatrywaniu zagadnienia powstania celów, które możemy określić jako intelektualne lub emocjonalne dążenie do osiągnięcia lub zrealizowania określonego stanu rzeczy (Rutkowska, 2003). Taki cel determinuje pedagogikę resocjalizacyjną także do dokonywania wyboru czynności umożliwiających realizację dobra jednostki na każdym etapie jej rozwoju. Właśnie tego rodzaju wychowanie resocjalizacyjne powinno zmierzać w kierunku celu wyznaczanego przez bytową strukturę człowieka (Sobczyszyn, 2014).

W tym znaczeniu Kazimierz Sośnicki przypisywał celom wychowania zadanie dokonywania zamierzonych modyfikacji w osobowości jednostek, co w odniesieniu do więźniów i osób nieprzystosowanych można ująć jako zadanie rozwijania cech dodatnich (ogólnoludzkich), korygowania powstałych wad, zapobiegania cechom niepożądanym (Sośnicki, 1967), ale także określenia obrazu osoby wychodzącej ze stanu nieprzystosowania społecznego i poszukiwania dróg realizacji zamierzonych celów oraz analizowania kierunków wywieranego wpływu.

W gruncie rzeczy jednak także w procesie resocjalizacji chodzi o pewien (przynajmniej minimalny) stopień dojrzałości, do jakiej należałoby dążyć. Ta sytuacja wymaga zatem przyjęcia założenia spełnienia wymogu pewnej podstawowej dojrzałości ludzkiej. Dogłębna „integracja” osoby, a więc osiągnięcie i utrzymywanie przez podopiecznego (byłego więźnia), jak i osób jemu towarzyszących pewnego stanu równowagi dynamicznej, jako wartości względnie stałej, jest także i w tym przypadku najważniejszym celem procesu resocjalizacji, tak jak jest nim w ogóle w odniesieniu do wychowania. Jeśli cel ten jest osiągnięty, można mówić o zakończeniu wspomnianego wyżej „celu minimum”.

Ponieważ nie możemy w naszym ujęciu kwestii skutecznej resocjalizacji pominąć innych osób, a zwłaszcza grup ludzkich i wspólnot, w jakie każdy człowiek jest włączony, powinniśmy zmierzać w kierunku promowania 
postępu całej społeczności. Właśnie na tym etapie i w tej konstelacji można byłoby dążyć do wymienionego wyżej „celu maksimum” w resocjalizacji. W ogóle chodzi tutaj o wysiłek budowania społeczności dorosłej i dojrzałej, który musi zmierzać - z konieczności - do czynienia dorosłych dojrzałymi. Jedynie dojrzałe osoby będą zdolne przyjąć i zachowywać nie tylko rozporządzenia społeczne, lecz także wartości i normy społeczne w duchu prawdziwej wolności. Przeciwnie, struktury i społeczności ludzkie tworzone przez ludzi niedojrzałych, także instytucje resocjalizacyjne (zarówno otwarte, jak i zamknięte), łatwo mogą przeradzać się w źródła dehumanizacji. Wydaje się, że ta kwestia i wartość, jaką jest dojrzałość, ciągle za mało jest brana pod uwagę w uwarunkowaniach oczekiwanych efektów resocjalizacji. „Dojrzałość ludzka” jest rzeczywistością dynamiczną i celem, ku któremu człowiek zmierza w całym swoim życiu. Zmierzają do niej także resocjalizowani. Jej osiąganie jest procesem, który powinien być stymulowany, ale również musimy umieć oczekiwać na właściwy czas i etap rozwoju, który umożliwi dokonanie istotnego postępu w rozwoju osoby.

Coraz większe zrozumienie zyskuje dzisiaj przekonanie, że przed osiągnięciem odpowiedniego wieku, biologicznie i psychicznie, osoba ludzka nie jest jeszcze zdolna do pełnej integracji. Brakuje jej doświadczenia, zbyt mały jest jej zmysł realizmu, nie ma stałości uczuciowej, a reagowanie zachodzi często na zasadzie sprzeciwu. Najczęściej właśnie na tym etapie dochodzi też do sytuacji konfliktu z prawem czy też odrzucenia wartości i norm społecznych czy moralnych. To wszystko sprawia, że we wczesnej młodości nie jest jeszcze możliwe nabycie cech dojrzałej osobowości i także innego rodzaju kryteriom powinien podlegać nie tylko proces resocjalizacji, lecz także rozpatrywania jego efektów czy skuteczności.

BIBLIOGRAFIA

Cichoń, W. (1980). Aksjologiczne podstawy teorii wychowania. Kraków: Wydawnictwo Literackie.

Corallo, G. (2010). Pedagogia. Vol. 1: L'educazione. Problemi di pedagogia generale. Roma: Armando.

CZerny, J. (1998). Zarys pedagogiki aksjologicznej. Katowice: UŚ.

Fullat, O., Genis, I. (1999). Sens et éducation. W: J. Houssaye (dir.), Éducation et philosophie. Approches contemporaines (s. 198-222). Paris: ESF.

GaŁKowski, J.W. (1996). Wychowanie a wart ości. Roczniki Nauk Społecznych, 24 (2), 20-28. Heschel, A.J. (2014). Kim jest człowiek? Łódź: Wydawnictwo Uniwersytetu Łódzkiego. 
Hildebrand, D. von (1982). Fundamentalne postawy moralne. W: D. von Hildebrand, J. KŁoCZowski, J. Paściak, J. Tischner (red.), Wobec wartości (s. 11-55). Poznań: W drodze.

Ingarden, R. (1975). Książeczka o człowieku. Kraków: Wydawnictwo Literackie.

KAMIŃSKI, S. (1986). Jak uporządkować rozmaite koncepcje wartości? W: S. SAWICKI (red.), O wartościowaniu w badaniach literackich (s. 7-24). Lublin: Redakcja Wydawnictw KUL.

Kunowski, S. (2003). Wartości w procesie wychowania. Kraków: Oficyna Wydawnicza „Impuls”.

Machel H. (2001). Psychospoleczne uwarunkowania pracy resocjalizacyjnej personelu więziennego. Gdańsk: Wydawnictwo Uniwersytetu Gdańskiego.

Machel, H. (2003). Więzienie jako instytucja karna i resocjalizacyjna. Gdańsk: Wydawnictwo Arche.

Musaio, M. (2010). Pedagogia della persona educabile. L'educazione tra interiorità e relazione. Milano: Vita e Pensiero.

Nowak, M. (2012). Pedagogiczny profil nauk o wychowaniu. Lublin: Wydawnictwo KUL.

Olbrycht, K. (2000). Prawda, dobro i piękno w wychowaniu człowieka jako osoby. Katowice: UŚ.

Rutkowska, D. (2003). Wpływ uprzedniej aktywizacji automatycznego vs refleksyjnego systemu wartościowania na operowanie pojęciami aksjologicznymi u osób o różnym stopniu ich ukształtowania. Przeglad Psychologiczny, 46 (2), 161-177.

Rylke, H., Klimowicz, G. (1992). Szkoła dla ucznia. Jak uczyć życia z ludźmi. Warszawa: Wydawnictwa Szkolne i Pedagogiczne.

Sobczak, S. (2008). Resocjalizacja w ujęciu pedagogicznym. W: B. Urban, J. M. Stanik (red.), Resocjalizacja (t. 1). Warszawa: Wydawnictwo Naukowe PWN.

SobCzyszyn, U. (2014). Wartości noetyczne w procesie resocjalizacji. Na przykładzie badań osadzonych po raz pierwszy w zakładach karnych Okręgu Lubelskiego. Niepublikowana praca doktorska, Katolicki Uniwersytet Lubelski Jana Pawła II, Lublin.

Sośnicki, K. (1967). Istota i cele wychowania. Warszawa: Nasza Księgarnia.

TARnowski, J. (1990). Jak wychowywać? Warszawa: ATK.

\section{AKSJOLOGIA WSPÓŁCZESNEJ PEDAGOGIKI RESOCJALIZACYJNEJ JAKO PODSTAWA JEJ SUKCESU}

\section{Streszczenie}

Życie człowieka charakteryzują wartości realizowane w wolności. Dotyczy to także resocjalizacji. Wartościami zajmuje się aksjologia, a w pedagogice - aksjologia wychowania. Główny problem artykułu sformułowano jako pytanie: Jaka jest rola wartości w sukcesie oddziaływań resocjalizacyjnych? W odpowiedzi na ten problem podjęto najpierw określenie roli wartości w wychowaniu i w pedagogice, następnie wskazano na specyficzne aspekty procesu resocjalizacji, aby w tym kontekście przedstawić zagadnienie roli wartości w procesie skutecznej resocjalizacji.

Słowa kluczowe: wartości; aksjologia; aksjologia wychowania; resocjalizacja; sukces; efekty. 


\title{
AXIOLOGY OF CONTEMPORARY RESOCIALIZATION PEDAGOGY AS THE BASIS FOR ITS SUCCESS
}

\begin{abstract}
Summary
A man's life are characterized by values implemented in freedom. This also applies the rehabilitation and treatment. Values and deals are the subject of interest of axiology and axiological education. The main problem of this article are formulated as question: What is the role of values in the success of the impact of correctional facilities? In response to this problem it was decided to specify the role of values in education and pedagogy, then it was indicated on the specific aspects of the process of rehabilitation, to take, in this context, the question of the role of values in the process of effective rehabilitation and treatment of the prisoners.
\end{abstract}

Key words: values; axiology; axiological education; rehabilitation; treatment; success; results. 